\title{
On the Mechanical Behavior of a New Single- Crystal Superalloy for Industrial Gas Turbine Applications
}

\author{
Atsushi Sato, Johan Moverare, Magnus Hasselqvist and Roger C. Reed
}

\section{Linköping University Post Print}

N.B.: When citing this work, cite the original article.

The original publication is available at www.springerlink.com:

Atsushi Sato, Johan Moverare, Magnus Hasselqvist and Roger C. Reed, On the Mechanical Behavior of a New Single-Crystal Superalloy for Industrial Gas Turbine Applications, 2012, Metallurgical and Materials Transactions. A, (43A), 7, 2302-2315.

http://dx.doi.org/10.1007/s11661-011-0995-2

Copyright: ASM International / Springer Verlag (Germany) http://www.asminternational.org/

One print or electronic copy may be made for personal use only. Systematic or multiple reproduction, distribution to multiple locations via electronic or other means, duplications of any material in this paper for a fee or for commercial purposes, or modification of the content of this paper are prohibited.

Postprint available at: Linköping University Electronic Press http://urn.kb.se/resolve?urn=urn:nbn:se:liu:diva-77791 


\title{
On the Mechanical Behavior of a New Single-Crystal Superalloy for Industrial Gas Turbine Applications
}

\begin{abstract}
ATSUSHI SATO, JOHAN J. MOVERARE, MAGNUS HASSELQVIST, and ROGER C. REED

The mechanical behavior of a new single-crystal nickel-based superalloy for industrial gas turbine (IGT) applications is studied under creep and out-of-phase (OP) thermomechanical fatigue (TMF) conditions. Neutron diffraction methods and thermodynamic modeling are used to quantify the variation of the gamma prime $\left(\gamma^{\prime}\right)$ strengthening phase around the $\gamma^{\prime}$ solvus temperature; these aid the design of primary aging heat treatments to develop either uniform or bimodal microstructures of the $\gamma^{\prime}$ phase. Under creep conditions in the temperature range $1023 \mathrm{~K}$ to $1123 \mathrm{~K}\left(750{ }^{\circ} \mathrm{C}\right.$ to $\left.850{ }^{\circ} \mathrm{C}\right)$, with stresses between 235 to $520 \mathrm{MPa}$, the creep performance is best with a finer and uniform $\gamma^{\prime}$ microstructure. On the other hand, the OP TMF performance improves when the $\gamma^{\prime}$ precipitate size is larger. Thus, the micromechanical degradation mechanisms occurring during creep and TMF are distinct. During TMF, localized shear banding occurs with the $\gamma^{\prime}$ phase penetrated by dislocations; however, during creep, the dislocation activity is restricted to the matrix phase. The factors controlling TMF resistance are rationalized.
\end{abstract}

DOI: $10.1007 / \mathrm{s} 11661-011-0995-2$

(C) The Minerals, Metals \& Materials Society and ASM International 2012

\section{INTRODUCTION}

NEW nickel-based superalloys ${ }^{[1,2]}$ are needed for hot section components, e.g., turbine blades and guide vanes, in the next-generation gas turbine engines required for power generation applications. Significant demands will be placed on these materials. For instance, excellent resistance to environmental attack is required, since the operating conditions and fuels used for these applications induce oxidation and corrosion; thus, the superalloys used will be distinct from those currently employed for aeroengine applications. Moreover, they must withstand the large mechanical loads necessary for efficient extraction of mechanical energy from the hot gas stream. Hence, creep $^{[1,2]}$ and fatigue ${ }^{[3,4]}$ must be resisted. Recently, a new grade of single-crystal superalloy was developed for such applications, which displays a good balance of environmental and mechanical properties. ${ }^{[5,6]}$ Its $\mathrm{Cr}$ content (at $15 \mathrm{wt}$ pct) is substantially greater than for existing single-crystal superalloys, which improves significantly the resistance to oxidation and corrosion. ${ }^{[7]}$

This article is concerned with the mechanical performance of this new single crystal superalloy. In common with most precipitation-hardened systems, the proper-

ATSUSHI SATO, Postdoctoral Student, and ROGER C. REED, Professor, are with the Department of Metallurgy and Materials, University of Birmingham, Edgbaston, Birmingham B15 2TT, United Kingdom. Contact e-mail: r.reed@bham.ac.uk JOHAN J. MOVERARE, Associate Professor, is with the Division of Engineering Materials, Department of Management and Engineering, Linköping University, 58183 Linköping, Sweden. MAGNUS HASSELQVIST, Specialist, is with Siemens Industrial Turbomachinery AB, 61283 Finspång, Sweden.

Manuscript submitted January 31, 2011.

Article published online January 19, 2012 ties displayed will depend in a sensitive fashion upon the microstructure developed during heat treatment; for this class of material, hardening is by the gamma prime $\left(\gamma^{\prime}\right)$ phase and thus conditioning of the microstructure at temperatures in and around the $\gamma^{\prime}$ solvus is expected to influence the mechanical properties displayed. Two distinct forms of mechanical response are studied as a function of the heat treatment applied: first, creep deformation, which is important due to the centrifugal loading experienced by the turbine blades in the engine $;^{[1,2]}$ and, second, thermomechanical fatigue (TMF), which is relevant particularly for smaller (aeroderivative) industrial gas turbines (IGTs) because of the interaction of thermal and mechanical strains arising from engine startup/cooldown. ${ }^{[8,9]}$ As mission requirements become more demanding, it is becoming apparent that the performance of the material under TMF conditions can be life limiting; however, historically, very much more attention has been paid to the provision of creep resistance. ${ }^{[10]}$ This is probably due to the significant extra difficulty imposed by the constraints of TMF testing; nonetheless, this situation needs to be corrected. Here, it is demonstrated that significant differences exist between the underlying micromechanisms of creep and TMF in these materials. This situation has ramifications for the performance of these materials under service loading conditions.

Figure 1 illustrates the difficulty that has traditionally been faced by the designers of IGTs. Existing off-theshelf superalloys fall into one of two distinct classes: (1) those of high $\mathrm{Al} / \mathrm{Cr}$ ratio, which exhibit good creep resistance but only moderate corrosion resistance, due to their limited $\mathrm{Cr}$ content (for example, CMSX-4 and Rene'N5, which are used for aeroengine applications); and (2) those of lower $\mathrm{Al} / \mathrm{Cr}$ ratio, which have better 
corrosion resistance but only moderate high-temperature strength (these tend to be polycrystalline alloys such as IN792). As Figure 1 indicates, a target design space exists for new corrosion-resistant IGT alloys of balanced $\mathrm{Al}$ and $\mathrm{Cr}$ contents. Also shown are isocontours of constant $\gamma^{\prime}$ fraction but of varying $\mathrm{Ta} / \mathrm{Al}$ ratios, which were used in the alloy design process for the new singlecrystal superalloy, denoted STAL-15. The higher Ta content is expected to improve the high-temperature strength but also to improve its castability. The new alloy was shown to exhibit excellent resistance to environmental degradation; ${ }^{[5]}$ the purpose of the present article is to study the alloy's mechanical performance.

\section{EXPERIMENTAL PROCEDURES}

The prototype nickel-based single-crystal superalloy STAL-15 investigated has composition Ni-5Co-15.5Cr1Mo-4W-4.6Al-8Ta-0.1 Hf (wt pct). An industrial scale investment casting facility at the University of Birmingham was used to prepare single-crystal castings in the form of 15-mm-diameter rods of length $150 \mathrm{~mm}$, using casting stock melted by Ross \& Catherall (Sheffield, United Kingdom). Three rods were cast in each run with a withdrawal speed of $\sim 200 \mathrm{~mm}$ per hour; the temperature gradient was $\sim 75 \mathrm{~K} / \mathrm{cm}$. Ceramic molds were used, which had been prepared from alumina, silica, and zircon in the usual way; the final mold thickness was $\sim 6 \mathrm{~mm}$. Casting was carried out under the vacuum of better than $10^{-4} \mathrm{~Pa}$. The bars were macroetched using $\mathrm{HCl}+5$ to 10 vol pct $\mathrm{H}_{2} \mathrm{O}_{2}$ solution to check for the presence of casting defects such as freckles. None were observed.

To remove microsegregation inherited from casting, an appropriate solutionizing procedure was designed. Pieces of the as-cast material were exposed to temperatures between $1533 \mathrm{~K}$ and $1593 \mathrm{~K} \quad\left(1260{ }^{\circ} \mathrm{C}\right.$ and $1320{ }^{\circ} \mathrm{C}$ ), at $20 \mathrm{~K}$ intervals, for 2 hours. The samples were first put into the furnace heated at $20 \mathrm{~K}$ lower than the target temperature; then, after 15 minutes, the temperature was increased by $+1 \mathrm{~K} / \mathrm{min}$ to the target temperature. To complement these measurements, the liquidus, solidus, and solvus temperatures were determined using differential scanning calorimetry (DSC). Specimens of size $2 \times 2 \times 2 \mathrm{~mm}$ cubic were cut from the fully heat-treated bar, and then inserted into a Netzsch DSC404C machine (Netzsch Instruments, Walsall, UK) in pure- $\mathrm{Al}_{2} \mathrm{O}_{3}$ crucibles and analyzed between $1073 \mathrm{~K}$ and $1673 \mathrm{~K}\left(800^{\circ} \mathrm{C}\right.$ and $\left.1400{ }^{\circ} \mathrm{C}\right)$. The heating and cooling rates used were 5 and $10 \mathrm{~K} / \mathrm{min}$, respectively. These experimental observations were compared with thermodynamic calculations, which indicated that the solidus temperature would be in the range $1581 \mathrm{~K}$ to $1588 \mathrm{~K}\left(1308^{\circ} \mathrm{C}\right.$ to $1315^{\circ} \mathrm{C}$, Table I), as discussed in further detail in Section III.

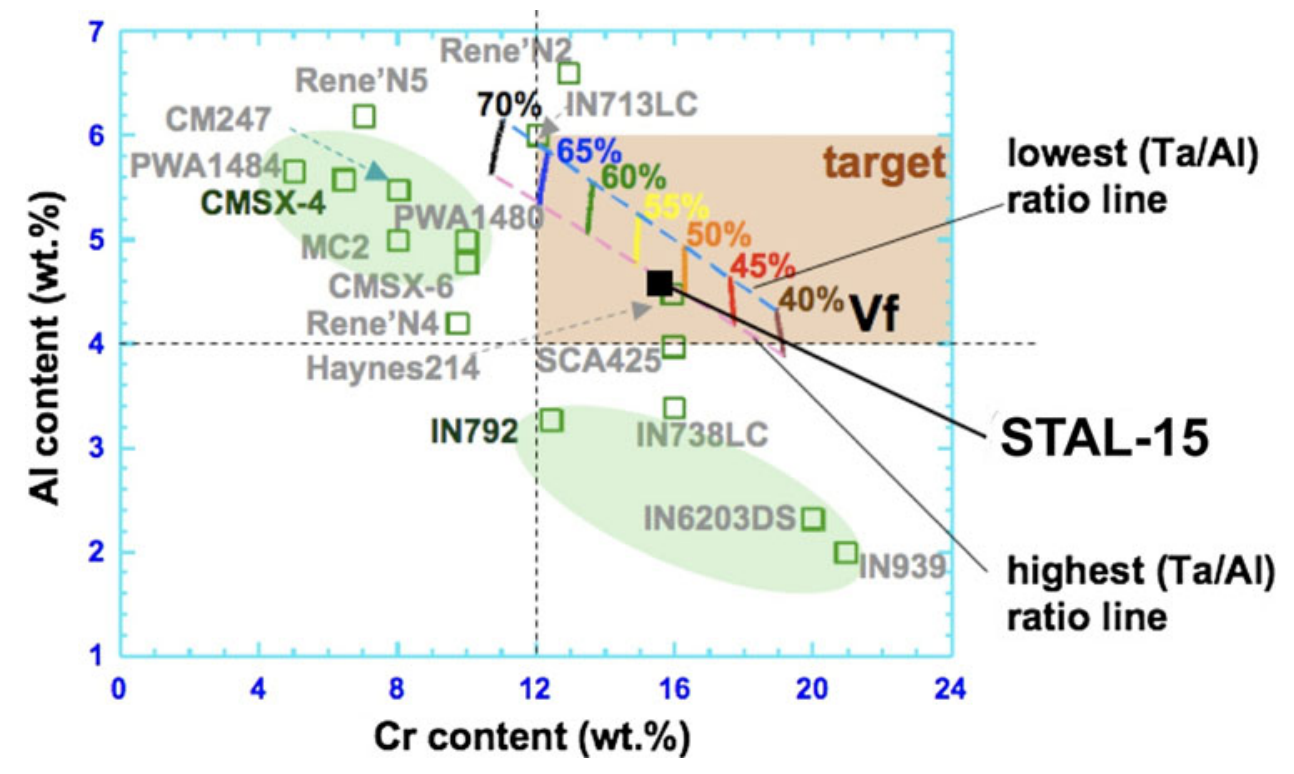

Fig. 1-Illustration of the locations of common nickel-based superalloys on a plot of $\mathrm{Cr}$ and $\mathrm{Al}$ contents, illustrating the location of the new STAL-15 alloy and the target design space.

Table I. Liquidus, Solidus, and Solvus Temperatures of the STAL-15 Alloy Measured by DSC and Calculated Using THERMO-CALC Software ${ }^{[11]}$

\begin{tabular}{lccr}
\hline & Liquidus $\left[\mathrm{K}\left({ }^{\circ} \mathrm{C}\right)\right]$ & Solidus $\left[\mathrm{K}\left({ }^{\circ} \mathrm{C}\right)\right]$ & Solvus $\left[\mathrm{K}\left({ }^{\circ} \mathrm{C}\right)\right]$ \\
\hline DSC & $1637\left(1364{ }^{\circ} \mathrm{C}\right)$ & $1591\left(1318^{\circ} \mathrm{C}\right)$ & $1469\left(1196{ }^{\circ} \mathrm{C}\right)$ \\
THERMO-CALC & $1634\left(136{ }^{\circ} \mathrm{C}\right)$ & $1589\left(1316^{\circ} \mathrm{C}\right)$ & $1446\left(1173{ }^{\circ} \mathrm{C}\right)$ \\
\hline
\end{tabular}


Several different primary-aging heat treatments were carried out to investigate the effect of differing precipitate morphologies on the mechanical properties. To aid with this, the volume fraction of the $\gamma^{\prime}$ phase (along with the lattice parameters of the $\gamma$ and $\gamma^{\prime}$ phases and the associated lattice misfit) was evaluated at temperatures of $1073 \mathrm{~K}\left(800{ }^{\circ} \mathrm{C}\right), 1173 \mathrm{~K}\left(900{ }^{\circ} \mathrm{C}\right)$, and $1273 \mathrm{~K}$ $\left(1000{ }^{\circ} \mathrm{C}\right)$ using the Engin-X neutron diffractometer at the ISIS facility, Rutherford Appleton Laboratory (Oxfordshire, United Kingdom). The second aging treatments for all alloys were $1123 \mathrm{~K}\left(850{ }^{\circ} \mathrm{C}\right)$ for 20 hours followed by air cooling. Fully heat-treated STAL-15 (i.e., solution treatment + first aging + second aging) was used. This enabled the (100) superlattice peak from the $\gamma^{\prime}$ phase and (200) peaks from both $\gamma$ and $\gamma^{\prime}$ phases to be obtained; the (100) superlattice peak was then fitted by a normal distribution, thus allowing the fitting of the composite peak from (200) by a two-peak gauss function because the position of the (200) superlattice contribution could be deduced. This procedure allowed the volume fraction of the $\gamma^{\prime}$ phase to be deduced from the ratio $S_{(100)} / S_{(200)}$ of the integrated intensities of the two reflections.

To determine the creep performance, specimens of 24.5-mm gage length and 5-mm diameter were machined from fully heat-treated single-crystal bars. The orientations of specimens were within $10 \mathrm{deg}$ from the $\langle 001\rangle$ direction. Testing was carried out under constant load conditions at $1023 \mathrm{~K} \quad\left(750{ }^{\circ} \mathrm{C}\right) / 520 \mathrm{MPa}, \quad 1023 \mathrm{~K}$ $\left(750{ }^{\circ} \mathrm{C}\right) / 455 \mathrm{MPa}, 1123 \mathrm{~K} \quad\left(850{ }^{\circ} \mathrm{C}\right) / 275 \mathrm{MPa}$, and $1123 \mathrm{~K}\left(850{ }^{\circ} \mathrm{C}\right) / 235 \mathrm{MPa}$, respectively. For TMF testing, specimens of 22-mm gage length and 6-mm-diameter were used. Out-of-phase (OP) TMF tests were carried out using an MTS 810 servohydraulic testing machine under strain control, with lower and upper temperatures of $373 \mathrm{~K}$ and $1223 \mathrm{~K}\left(100{ }^{\circ} \mathrm{C}\right.$ and $\left.950{ }^{\circ} \mathrm{C}\right)$, respectively, and with the mechanical strain range, $\Delta \varepsilon_{\text {mech }}$, set at values up to 0.9 pct. All tests were carried out with a strain ratio of $R=\varepsilon_{\min } / \varepsilon_{\max }=-\infty$. Note that in order to achieve a stabilized mean stress early in the tests, a 20-hour hold time was applied at the maximum temperature of the first cycle; however, a 5 -minute hold time was applied in the later cycles. This combination of $R$ ratio and longer hold time in the first cycle was chosen, because it is believed to better represent the service conditions experienced in the IGT.

Finally, transmission electron microscopy (TEM) was carried out as follows. Discs of diameter $3 \mathrm{~mm}$ were ground mechanically to $\sim 150-\mu \mathrm{m}$ thickness. They were then polished electrochemically by the twin jet method, using an $\mathrm{HClO}_{4}+80 \mathrm{vol}$ pet ethanol solution at $273 \mathrm{~K}$ $\left(0{ }^{\circ} \mathrm{C}\right)$, using 10 to $30 \mathrm{~V}$ direct current.

\section{RESULTS}

\section{A. Characterization of Solvus Temperature and Gamma Prime Approach Curve}

Optical micrographs of as-cast STAL-15 exposed at $1533 \mathrm{~K}\left(1260{ }^{\circ} \mathrm{C}\right), 1553 \mathrm{~K}\left(1280{ }^{\circ} \mathrm{C}\right), 1573 \mathrm{~K}\left(1300{ }^{\circ} \mathrm{C}\right)$, and $1593 \mathrm{~K}\left(1320^{\circ} \mathrm{C}\right)$ for 2 hours are given in Figure 2. Note that the casting direction is vertical so that the difference in contrast is due to the scale of the dendritic structure inherited from casting; the microporosity resides in the interdendritic regions. Figure 2 indicates that exposure at $1593 \mathrm{~K}\left(1320^{\circ} \mathrm{C}\right)$ caused incipient melting, but lower temperatures (Figures 2(a) through (c)) did not. Therefore, the solution treatment chosen for STAL-15 was $1553 \mathrm{~K}\left(1280{ }^{\circ} \mathrm{C}\right) 1$ hour $\rightarrow 1573 \mathrm{~K}$ $\left(1300{ }^{\circ} \mathrm{C}\right) 5$ hours, followed by air cooling. This was consistent with the results of the DSC calorimetry,
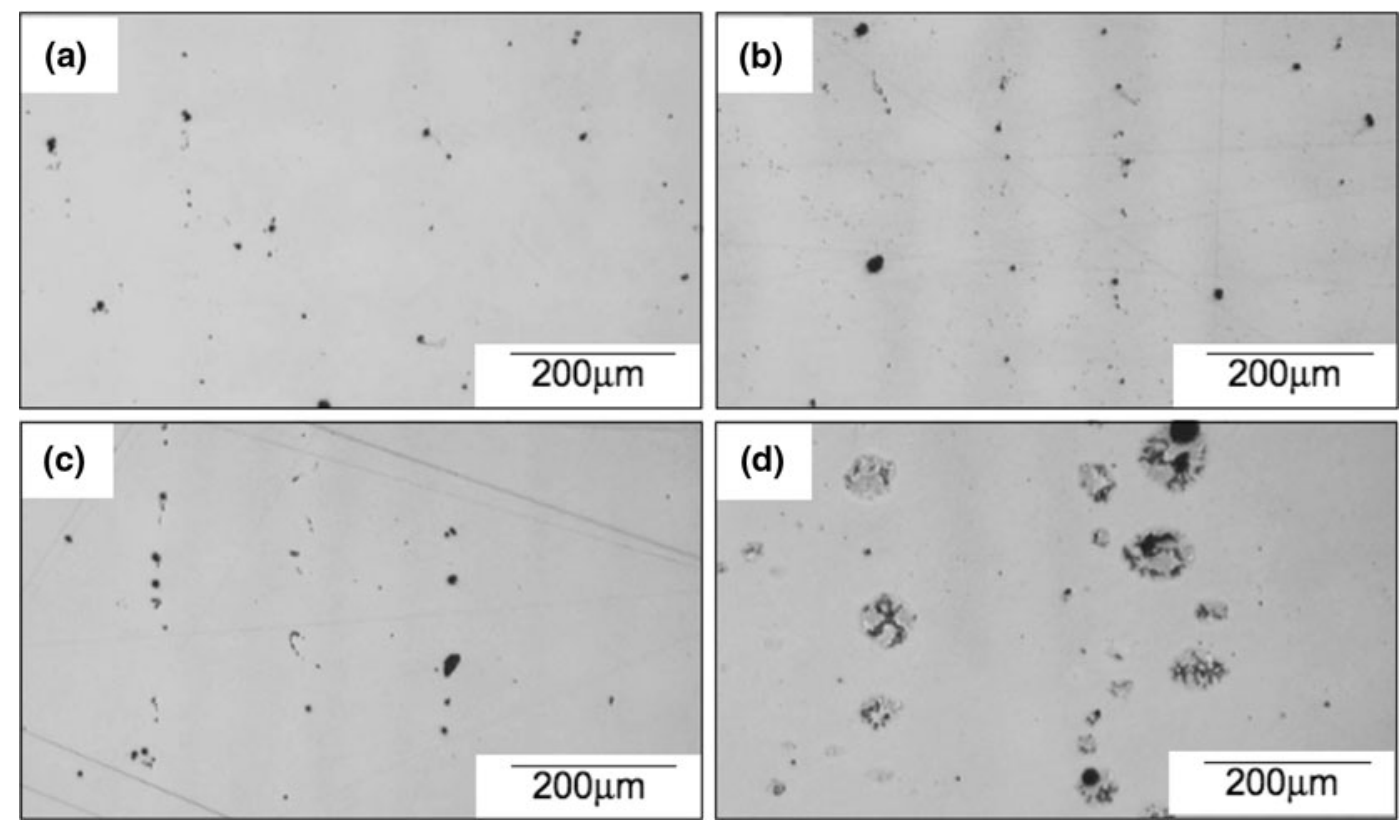

Fig. 2-Low-magnification optical micrographs of solution-treated STAL-15 exposed at $(a) 1533 \mathrm{~K}\left(1260{ }^{\circ} \mathrm{C}\right),\left(\right.$ b) $1553 \mathrm{~K}\left(1280{ }^{\circ} \mathrm{C}\right),(c) 1573 \mathrm{~K}$ $\left(1300{ }^{\circ} \mathrm{C}\right)$, and $(d) 1593 \mathrm{~K}\left(1320{ }^{\circ} \mathrm{C}\right)$ for $2 \mathrm{~h}$, respectively. Note in (d) the incipient melting at the interdendritic regions. 
which indicated that the solidus temperature is $1591 \mathrm{~K}$ $\left(1318{ }^{\circ} \mathrm{C}\right)$, the liquidus temperature $1637 \mathrm{~K}\left(1364{ }^{\circ} \mathrm{C}\right)$, and the solvus temperature $1469 \mathrm{~K}\left(1196{ }^{\circ} \mathrm{C}\right)$, as shown in Table I. These estimates are consistent with those made using THERMO-CALC and a thermodynamic databank. ${ }^{[11]}$ Figure 3 illustrates how the volume fraction of the $\gamma^{\prime}$ phase varies with respect to temperature; this may be termed the $\gamma^{\prime}$ approach curve. Plotted are the data from the neutron diffractometry (i.e., $S_{(100)}$ $\left.S_{(200)}\right)$, but also data deduced from the DSC (at $1473 \mathrm{~K}$ $\left.\left(1200{ }^{\circ} \mathrm{C}\right)\right)$ and the metallography (at $1123 \mathrm{~K}\left(850{ }^{\circ} \mathrm{C}\right)$ ). The DSC result indicates that the volume fraction of $\gamma^{\prime}$ in the STAL-15 alloy reduces to zero at $1469 \mathrm{~K}$ $\left(1196{ }^{\circ} \mathrm{C}\right)$, the solvus temperature. The $\gamma^{\prime}$ approach curve aids in the design of the primary heat treatment schedules (Section III-B). Neutron diffraction analysis confirmed the lattice misfit (Figure 4): slightly negative, yet small; this should aid in the retention of mechanical properties during service.

\section{B. Optimization of Heat Treatment and Gamma Prime Microstructure}

The effect of temperature and time on the $\gamma^{\prime}$ microstructure developed during primary aging was studied, since these need to be chosen carefully for optimized mechanical properties. ${ }^{[12]}$ Figure 5 shows micrographs of fully heat-treated STAL-15 with different first aging conditions. The primary $\gamma^{\prime}$ particles coarsen with increasing temperature and time, consistent with wellestablished theory. ${ }^{[13,14]}$ Moreover, the amount of primary $\gamma^{\prime}$ decreases with increasing aging temperature, as this approaches the $\gamma^{\prime}$ solvus temperature of $1469 \mathrm{~K}$ $\left(1196{ }^{\circ} \mathrm{C}\right)$. The $\gamma^{\prime}$ morphologies of Figure 5 were further analyzed using image-processing methods (Figure 6 and

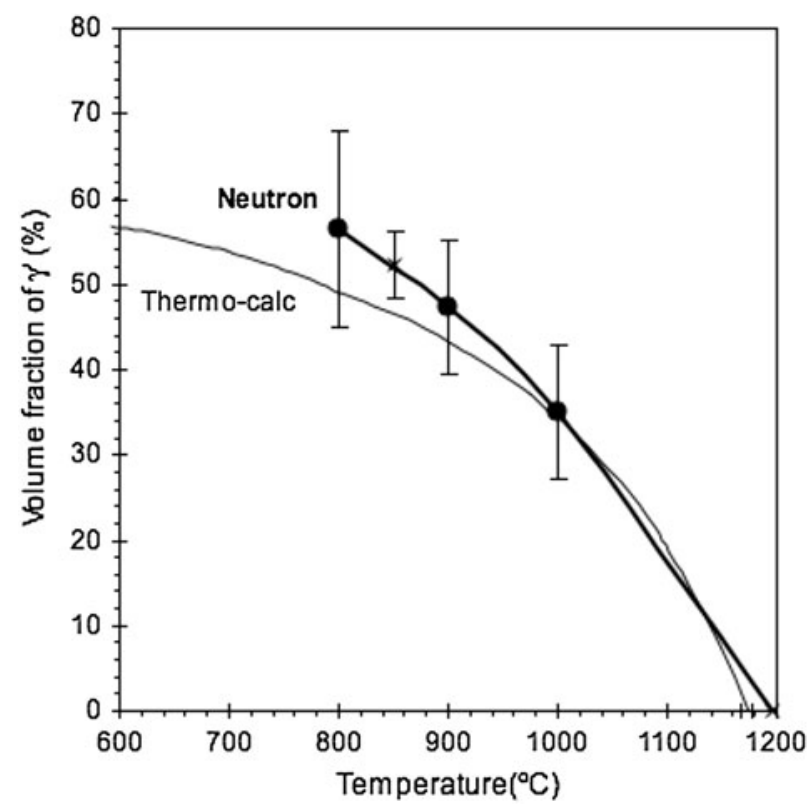

Fig. 3-Variation of the fraction of the $\gamma^{\prime}$ phase for STAL-15 with respect to temperature. Note that the dotted line represents the result from THERMO-CALC with Ni-database ver. $6^{[11]}$
Table II); based upon the LSW theory and associated content from the literature, ${ }^{[1-20]}$ the coarsening behavior of Figure 5 was as expected. Figure 7 illustrates the microstructures whose mechanical properties are studied in the latter parts of the article. Microstructure 1 in Figure 7 (a) exhibits a traditional uniform $\gamma / \gamma^{\prime}$ distribution; it was developed by aging at $1373 \mathrm{~K}\left(1100^{\circ} \mathrm{C}\right)$ for 6 hours, followed by air cooling. Microstructures 2 and 3 were developed by aging at $1393 \mathrm{~K}\left(1120^{\circ} \mathrm{C}\right)$ for 24 hours and $1433 \mathrm{~K}\left(1160^{\circ} \mathrm{C}\right)$ for 4 hours, respectively, followed by air cooling. Microstructures 2 and 3 were developed to be deliberately bimodal. The heat treatment conditions of STAL-15 investigated here are summarized in Table III.

\section{Creep Behavior}

The creep curves measured for the three distinct heat treatment conditions are given in Figure 8. It was found that microstructure 1 (uniform) performed the best for each of the four creep conditions chosen. The associated creep strain rate $v s$ strain curves are given in Figure 9; with regard to the minimum creep rate exhibited, one finds that (1) this is generally lower for microstructure 1 and (2) the effect of microstructural condition is greater at the lower temperature/higher stress regime. The creep results are summarized using a Larson-Miller plot (LMP) in Figure 10, using both the time to 1 pet strain but also the time to rupture. Once again, the time to $1 \mathrm{pct}$ creep falls in the order microstructure $1>$ microstructure

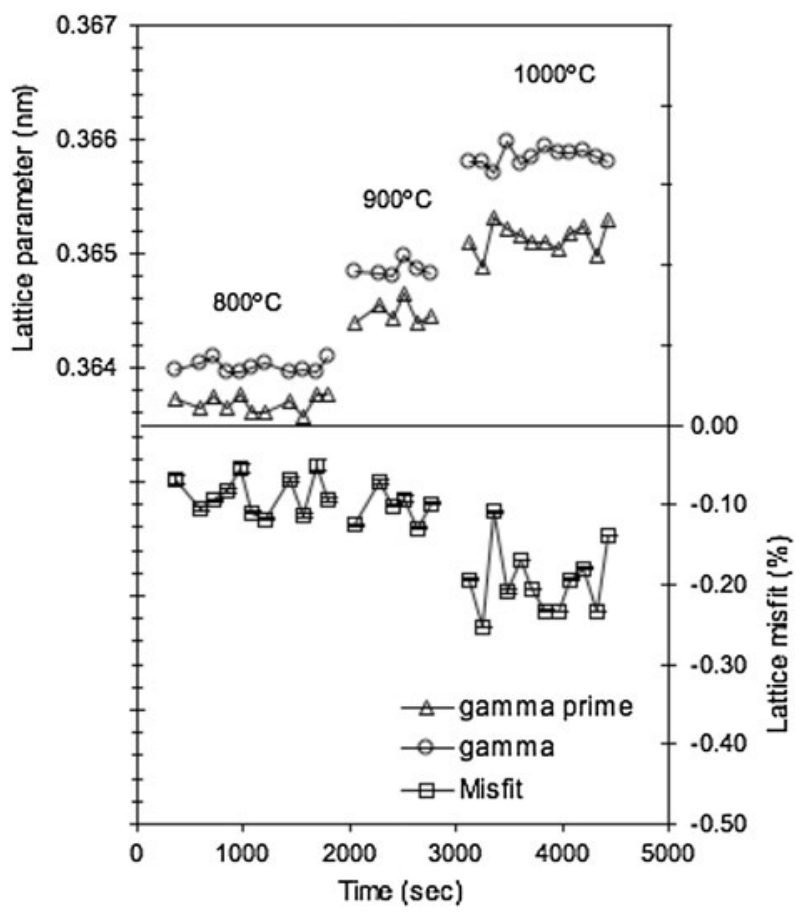

Fig. 4-Experimental data for the lattice parameters of the $\gamma$ and $\gamma^{\prime}$ phases and the associated lattice misfit in STAL-15 analyzed at $1073 \mathrm{~K}\left(800{ }^{\circ} \mathrm{C}\right), 1173 \mathrm{~K}\left(900{ }^{\circ} \mathrm{C}\right)$, and $1273 \mathrm{~K}\left(1000{ }^{\circ} \mathrm{C}\right)$ by in-situ neutron diffraction. Note that the first aging condition was $1373 \mathrm{~K}$ $\left(1100{ }^{\circ} \mathrm{C}\right)$ for $4 \mathrm{~h}$. 


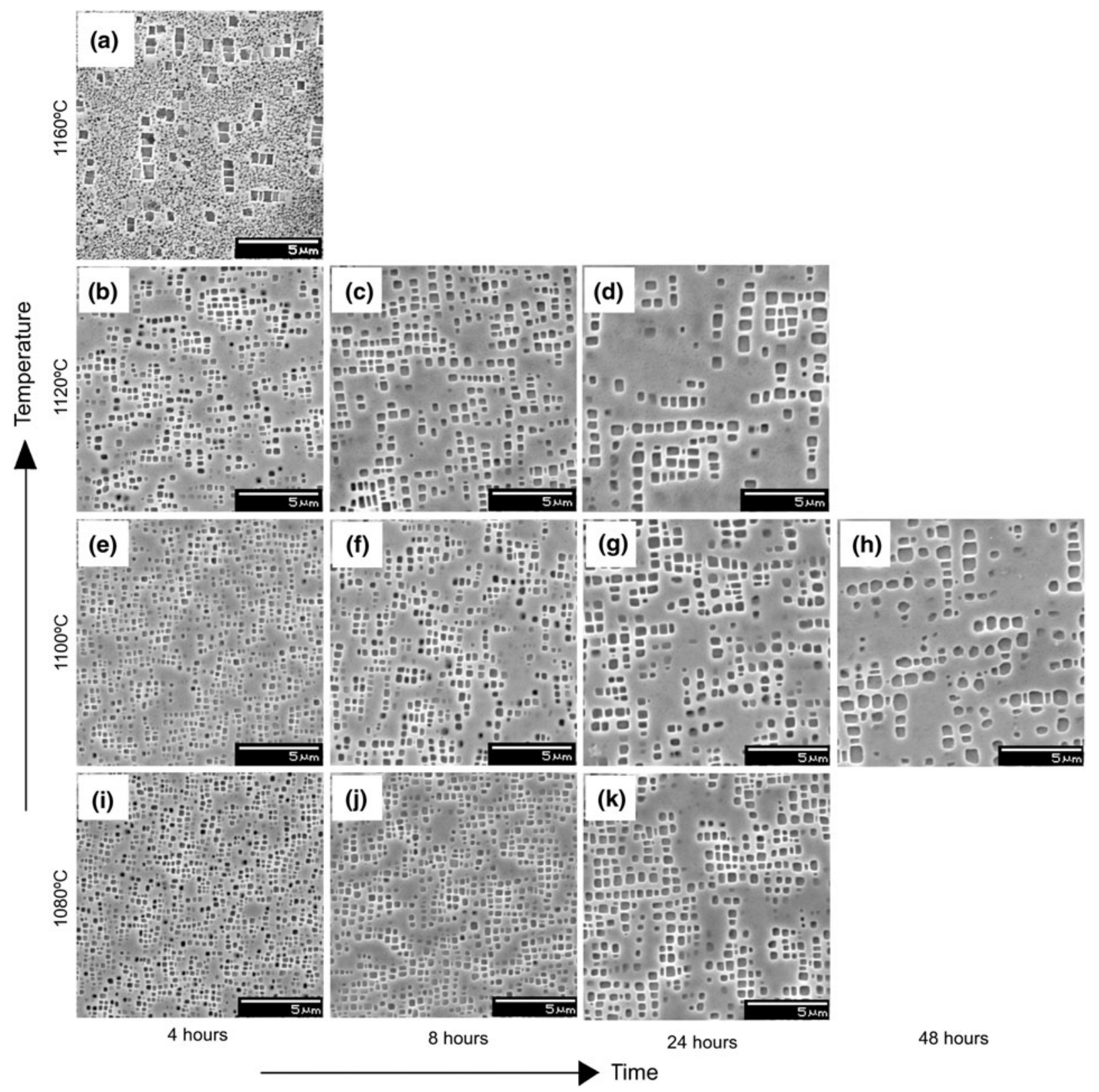

Fig. 5-Scanning electron micrographs of fully heat-treated STAL-15 with different first aging conditions: $(a) 1433 \mathrm{~K}\left(1160{ }^{\circ} \mathrm{C}\right) 4 \mathrm{~h},(b) 1393 \mathrm{~K}$ $\left(1120^{\circ} \mathrm{C}\right) 4 \mathrm{~h},(c) 1393 \mathrm{~K}\left(1120^{\circ} \mathrm{C}\right) 8 \mathrm{~h},(d) 1393 \mathrm{~K}\left(1120^{\circ} \mathrm{C}\right) 24 \mathrm{~h},(e) 1373 \mathrm{~K}\left(1100{ }^{\circ} \mathrm{C}\right) 4 \mathrm{~h},(f) 1373 \mathrm{~K}\left(1100{ }^{\circ} \mathrm{C}\right) 8 \mathrm{~h},(g) 1373 \mathrm{~K}\left(1100{ }^{\circ} \mathrm{C}\right)$ $24 \mathrm{~h},(h) 1373 \mathrm{~K}\left(1100{ }^{\circ} \mathrm{C}\right) 48 \mathrm{~h},(i) 1353 \mathrm{~K}\left(1080^{\circ} \mathrm{C}\right) 4 \mathrm{~h},(j) 1353 \mathrm{~K}\left(1080{ }^{\circ} \mathrm{C}\right) 8 \mathrm{~h}$, and $(k) 1353 \mathrm{~K}\left(1080{ }^{\circ} \mathrm{C}\right) 24 \mathrm{~h}$, respectively. Note that solution treatments, second aging conditions, and cooling conditions are the same in all cases.

$2>$ microstructure 3 . One can see that, while the creep performance falls short of the Re-containing alloy CMSX-4, the creep rupture performance approaches that of IN792, which was one of the goals of the STAL15 alloy development project.

Figure 11 illustrates the microstructure of STAL-15 after creep rupture. No topologically closed packed (TCP) phases were observed, indicating that, despite the significant alloying with respect to $\mathrm{Cr}$, the alloy is stable. No evidence of $\gamma^{\prime}$ cutting was observed, and $\gamma^{\prime}$ rafting was very limited, being restricted to microstructure 1 crept at $1123 \mathrm{~K}\left(850^{\circ} \mathrm{C}\right)$ for 2303 hours (Figure 12).
These findings were further confirmed by TEM. Figure 13 shows micrographs after creep rupture test at (a) $1123 \mathrm{~K} \quad\left(850^{\circ} \mathrm{C}\right) / 275 \mathrm{MPa}$ and (b) $1023 \mathrm{~K}$ $\left(750{ }^{\circ} \mathrm{C}\right) / 520 \mathrm{MPa}$ for microstructure 3. At $1123 \mathrm{~K}$ $\left(850^{\circ} \mathrm{C}\right) / 275 \mathrm{MPa}$, no dislocation activity was found within the $\gamma^{\prime}$ precipitates (Figure 13(a)). Very high dislocation density at primary $\gamma^{\prime} /$ matrix interfaces was observed; in other words, dislocations at secondary $\gamma^{\prime} /$ matrix interface were rather dispersed. Only at the lowest temperature and highest stress condition of $1023 \mathrm{~K}\left(750^{\circ} \mathrm{C}\right) / 520 \mathrm{MPa}$ were any single dislocations seen within the primary $\gamma^{\prime}$. 


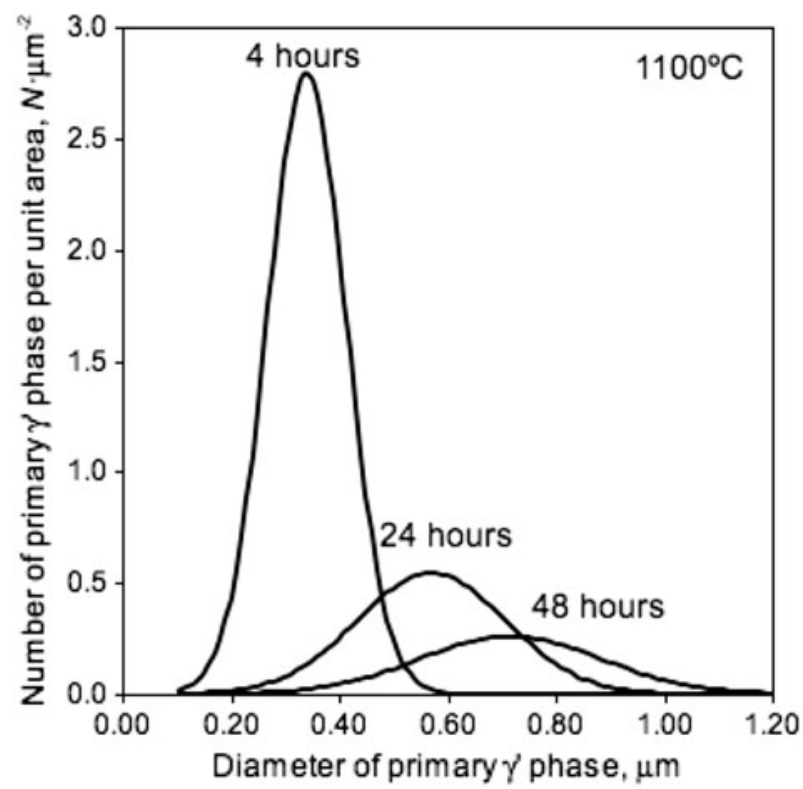

Fig. 6-Particle size distribution curves after aging for 4, 24, and $48 \mathrm{~h}$ at $1373 \mathrm{~K}\left(1100^{\circ} \mathrm{C}\right)$.

\section{TMF Behavior}

Although the creep performance of the new alloy is somewhat inferior to that of CMSX-4, the performance in TMF was found to approach that of this alloy; this is significant and has ramifications for the gas turbine users. In Figure 14, the relationship between the mechanical strain range used during the OP-TMF tests and the number of cycles to failure is given. Also given are data from the literature ${ }^{[21-23]}$ for CMSX-4 and IN792 acquired using identical testing methods. A number of important points emerge. First, consistent with its lower elastic modulus along the [001] testing direction, the TMF performance of STAL-15 is superior to that of the polycrystalline alloy IN792. Second, it is apparent that the TMF life is influenced by the microstructural state induced by heat treatment. In particular, bimodal microstructures are found to be superior to the uniform one; microstructure 2 exhibits the best TMF performance, with microstructure 1, best in creep, displaying the worst. Figure 15 illustrates stabilized hysteresis loops at midlives for the three microstructures, in this case, for the mechanical strain range of 0.8 pct. Note that the minimum stress in the

Table II. Summary of Stereological Data for the Distribution of the $\gamma^{\prime}$ Phase after Different First Aging Heat Treatments; Note That the Area Constants $A$ below Are to Calibrate the Height of Each Normal Distribution (Commonly the Number of Particles $N$ ) to Number of Particles Per Unit Area $\left(N \mu \mathrm{m}^{-2}\right)$

\begin{tabular}{lcccr}
\hline Temp. $\left[\mathrm{K}\left({ }^{\circ} \mathrm{C}\right)\right]$ & Time $(\mathrm{h})$ & Area Constant, $A$ & Average Diameter of $\gamma^{\prime}(\mu \mathrm{m})$ & Standard Deviation $(\mu \mathrm{m})$ \\
\hline $1353\left(1080^{\circ} \mathrm{C}\right)$ & 24 & 0.1511 & 0.5450 & 0.1122 \\
$1373\left(1100^{\circ} \mathrm{C}\right)$ & 4 & 0.5085 & 0.3405 & 0.0726 \\
& 6 & $0.7107^{*}$ & 0.3944 & 0.0829 \\
& 24 & 0.1866 & 0.5708 & 0.1372 \\
$1393\left(1120^{\circ} \mathrm{C}\right)$ & 48 & 0.1088 & 0.7171 & 0.1676 \\
$1433\left(1160^{\circ} \mathrm{C}\right)$ & 24 & 0.2293 & 0.4892 & 0.82 \\
& 4 & 0.0996 & 0.6635 & 0.1128 \\
\end{tabular}

*Different etching condition applied.
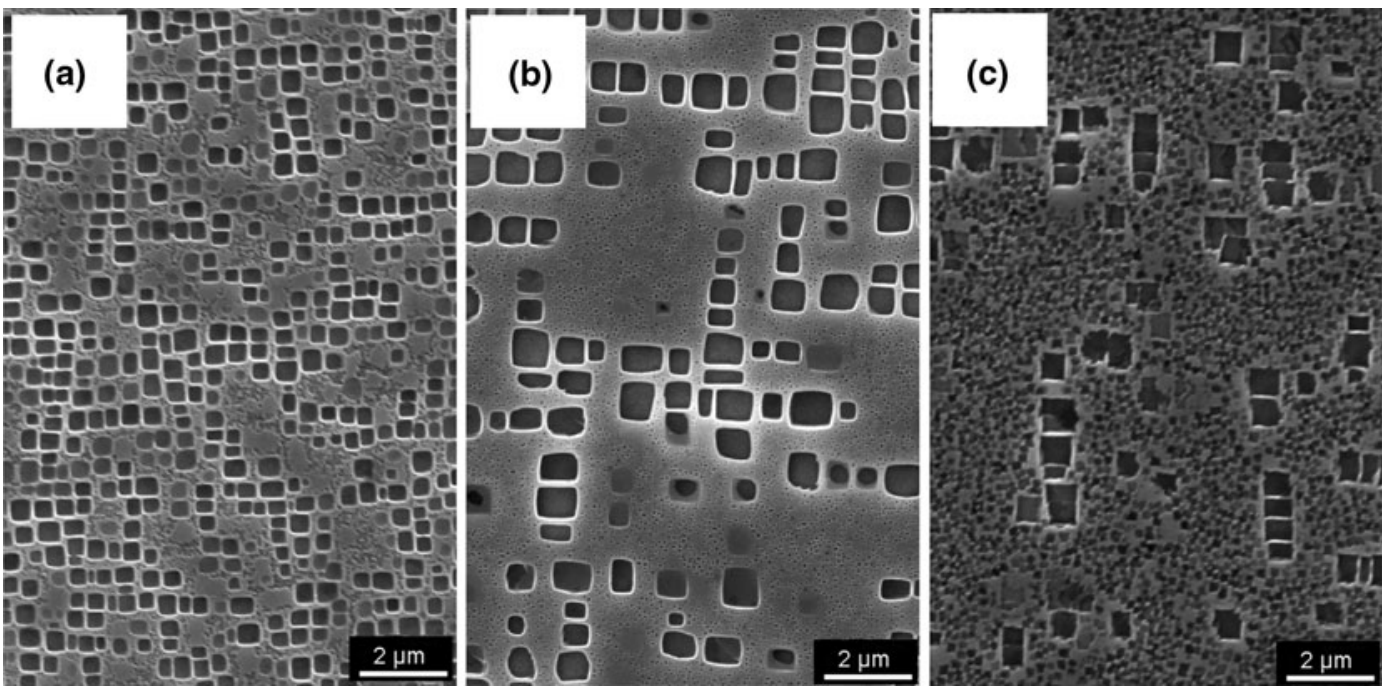

Fig. 7-Scanning electron micrographs of STAL-15 with different first aging conditions of $(a) 1373 \mathrm{~K}\left(1100{ }^{\circ} \mathrm{C}\right) 6 \mathrm{~h}$, (b) $1393 \mathrm{~K}\left(1120{ }^{\circ} \mathrm{C}\right) 24 \mathrm{~h}$, and $(c) 1433 \mathrm{~K}\left(1160^{\circ} \mathrm{C}\right) 4 \mathrm{~h}$, respectively. These are denoted $(a)$ microstructure $1,(b)$ microstructure 2 , and $(c)$ microstructure 3 in this article. 


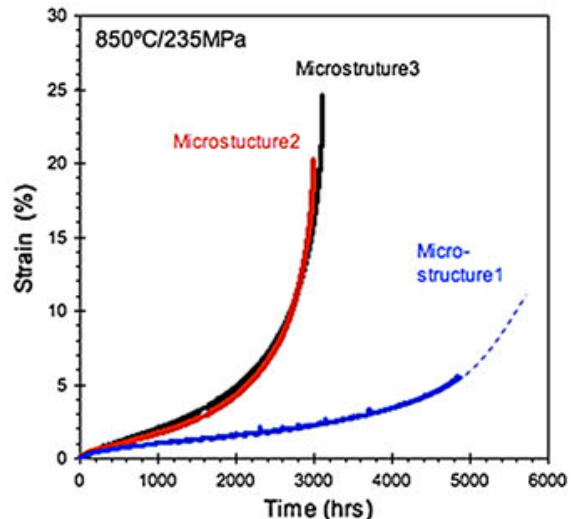

(a)

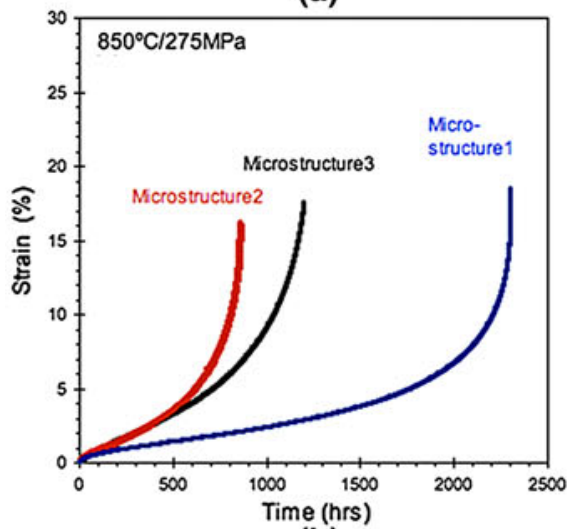

(b)

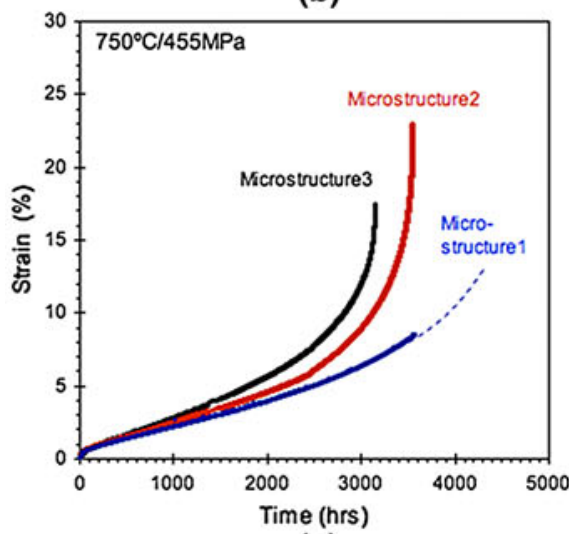

(c)

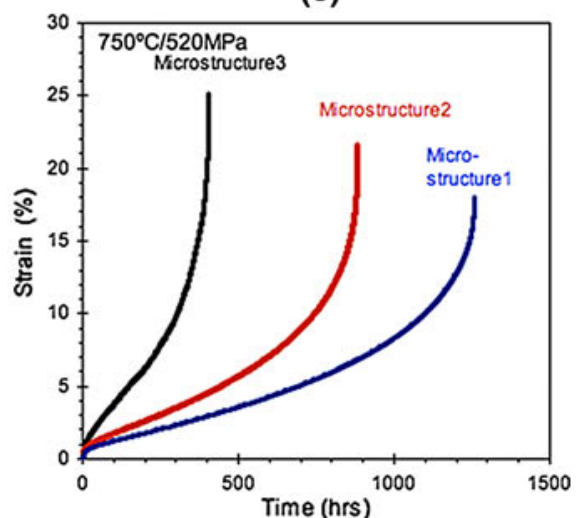

(d)

Fig. 8 - Creep strain $v s$ time curves for STAL-15 at different creep conditions.

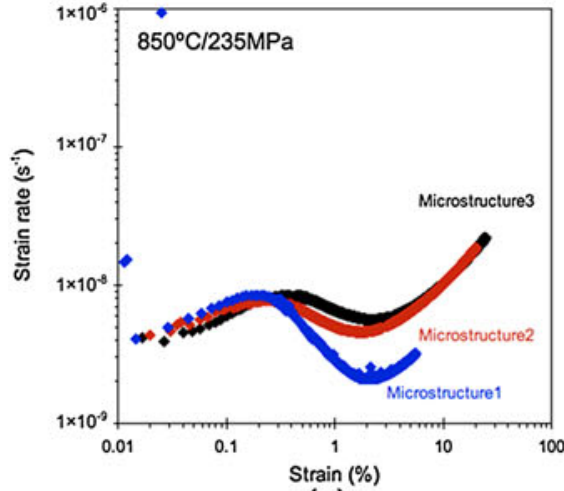

(a)

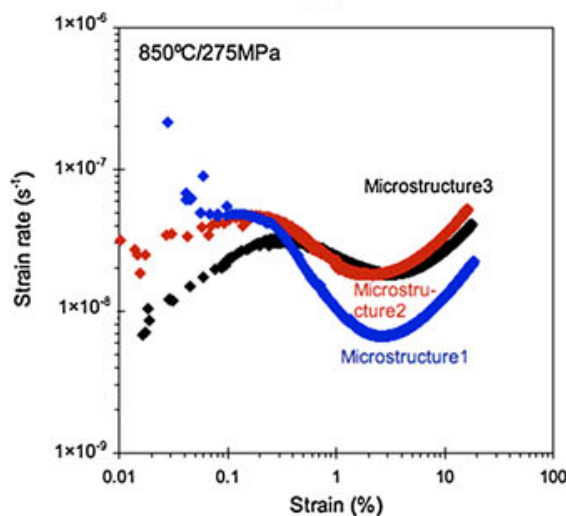

(b)

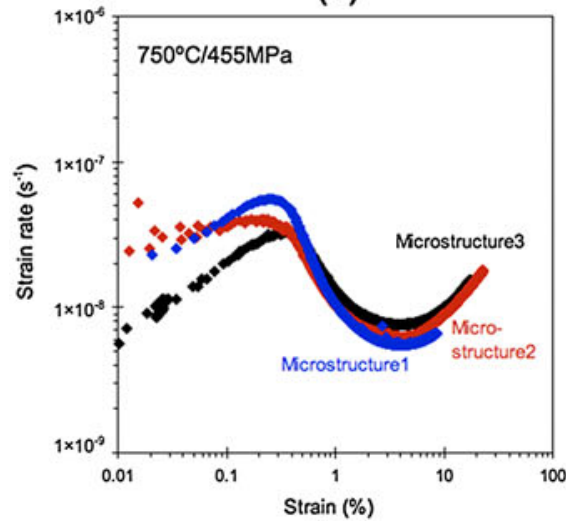

(c)

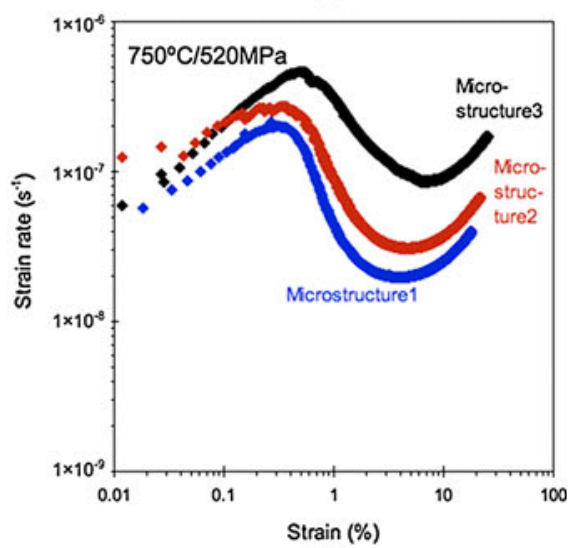

(d)

Fig. 9- Creep strain vs strain curves for STAL-15 at different creep conditions. 
Table III. Heat Treatment Conditions Used for the STAL-15 Superalloy (AC: Air Cooling)

\begin{tabular}{lccc}
\hline & Solution Treatment & First Aging & Second Aging \\
\hline Microstructure 1 & $1553 \mathrm{~K}\left(1280^{\circ} \mathrm{C}\right) 1 \mathrm{~h} \rightarrow 1573 \mathrm{~K}\left(1300^{\circ} \mathrm{C}\right) 5 \mathrm{~h} \mathrm{AC}$ & $1373 \mathrm{~K}\left(1100^{\circ} \mathrm{C}\right) 6 \mathrm{~h} \mathrm{AC}$ & $1123 \mathrm{~K}\left(850{ }^{\circ} \mathrm{C}\right) 20 \mathrm{~h} \mathrm{AC}$ \\
Microstructure 2 & & $1393 \mathrm{~K}\left(1120^{\circ} \mathrm{C}\right) 24 \mathrm{~h} \mathrm{AC}$ & \\
Microstructure 3 & & $1433 \mathrm{~K}\left(1160{ }^{\circ} \mathrm{C}\right) 4 \mathrm{~h} \mathrm{AC}$ & \\
\hline
\end{tabular}

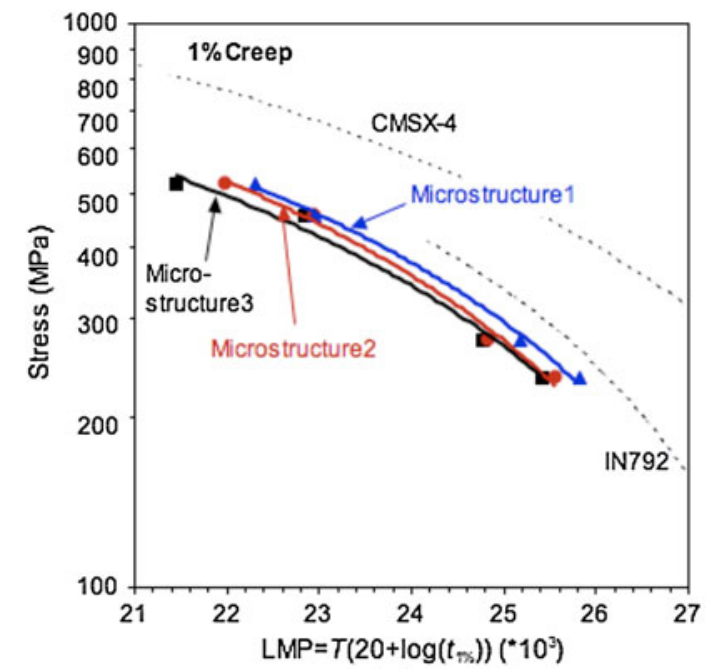

(a)

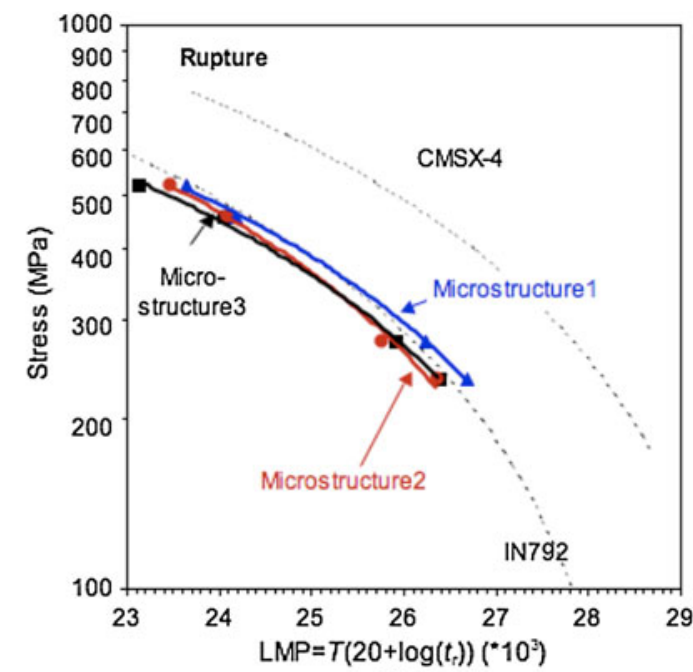

(b)

Fig. 10 - Larson-Miller plots of STAL-15 with three different microstructures for $(a) 1$ pct creep times and (b) creep rupture times. For comparison, the location of data for the IN792 polycrystalline alloy and the CMSX-4 single-crystal superalloy are given.
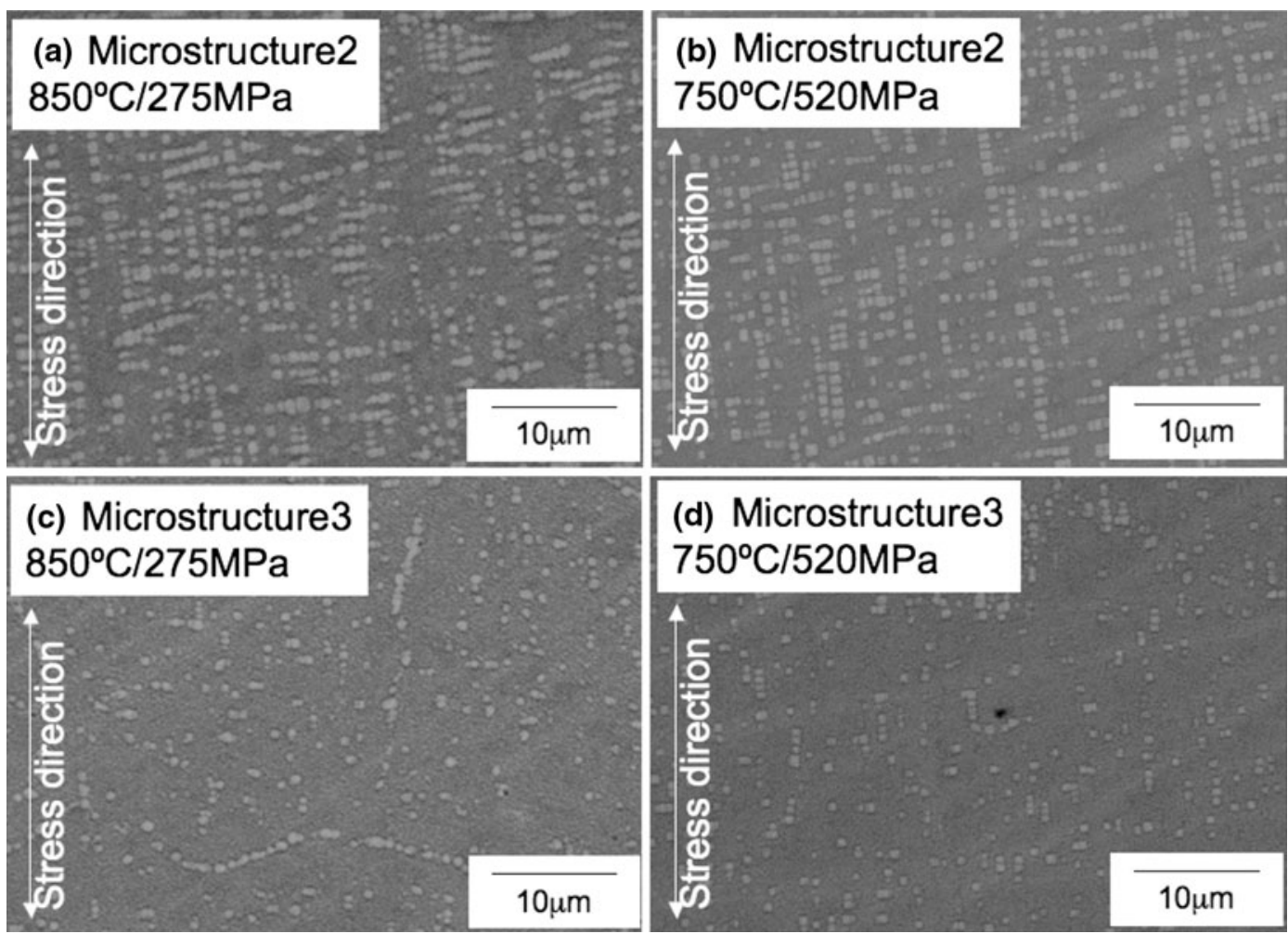

Fig. $11-$ Micrographs of STAL-15 after creep rupture testing at $1123 \mathrm{~K}\left(850{ }^{\circ} \mathrm{C}\right) / 275 \mathrm{MPa}$ and $1023 \mathrm{~K}\left(750{ }^{\circ} \mathrm{C}\right) / 520 \mathrm{MPa}$. Note that all images were obtained at a distance $10 \mathrm{~mm}$ away from the rupture surface. 
stabilized loops is lowest for microstructure 3 and greatest for microstructure 1, in agreement with the static creep result, which found that microstructure 3 creeps the fastest and microstructure 1 the slowest. This point is discussed further in Section IV.

Figure 16 illustrates the microstructure of STAL-15 after TMF testing. The fracture surface had a tendency to lie about $45 \mathrm{deg}$ from the direction of applied stress. Furthermore, across the cross section, significant numbers of slip bands were observed with subsequent crack propagation occurring along these. Occasionally, recrystallization was observed along the slip band as well (Figure 17). Additionally, there was strong evidence within the slip band (Figure 18) of the $\gamma \gamma^{\prime}$ rafts (orientated along the stress axis due to the compressive

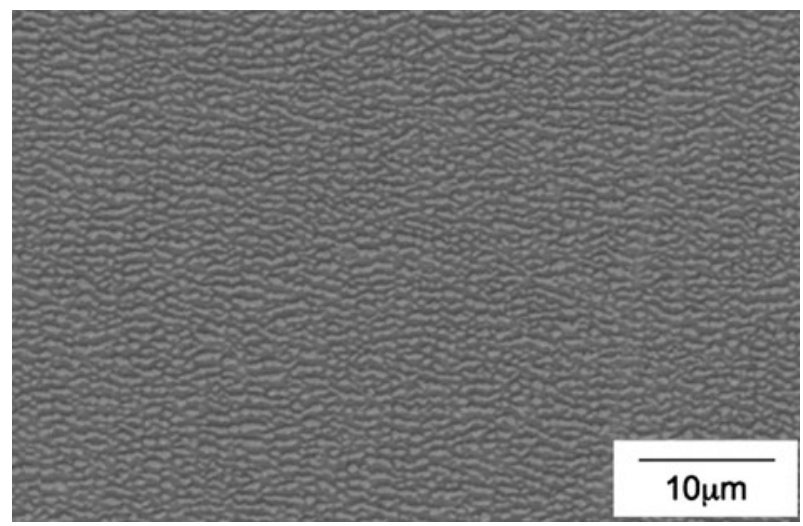

Fig. 12-SEM micrographs of microstructure 1 after $1123 \mathrm{~K}$ $\left(850{ }^{\circ} \mathrm{C}\right) / 275 \mathrm{MPa}$. A degree of rafting is present.

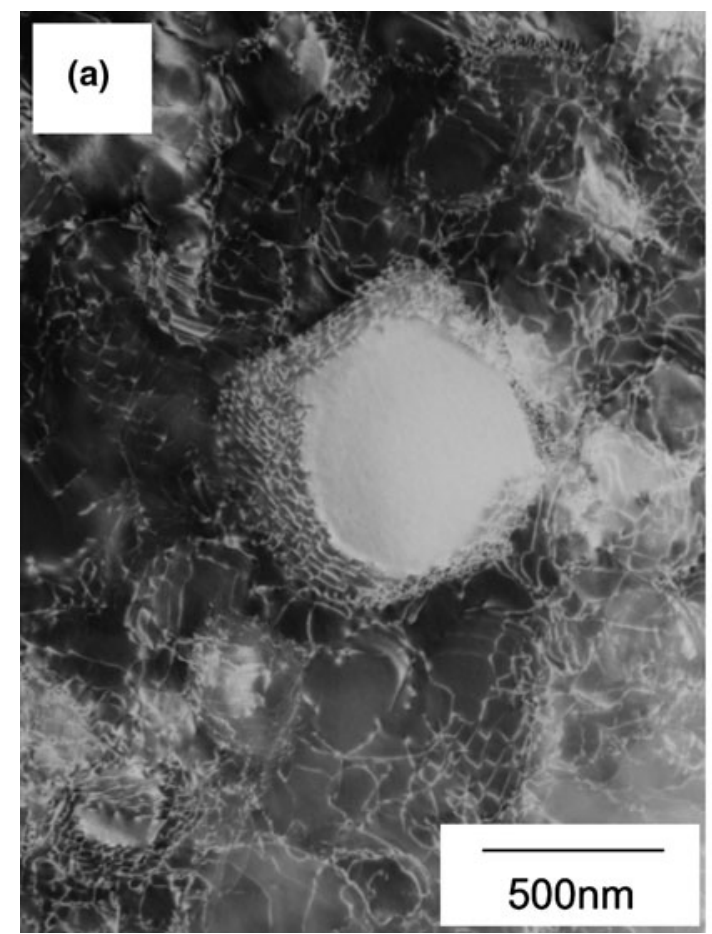

stress generated and consistent with the negative misfit determined in Section III-A) being sheared.

Finally, Figure 19 illustrates TEM micrographs of STAL-15 after TMF testing for microstructure 2. Necessarily due to the specimen preparation technique employed, the TEM specimens were taken somewhat away from the fracture surfaces. No significant micromechanical deformation was observed, with the dislocation

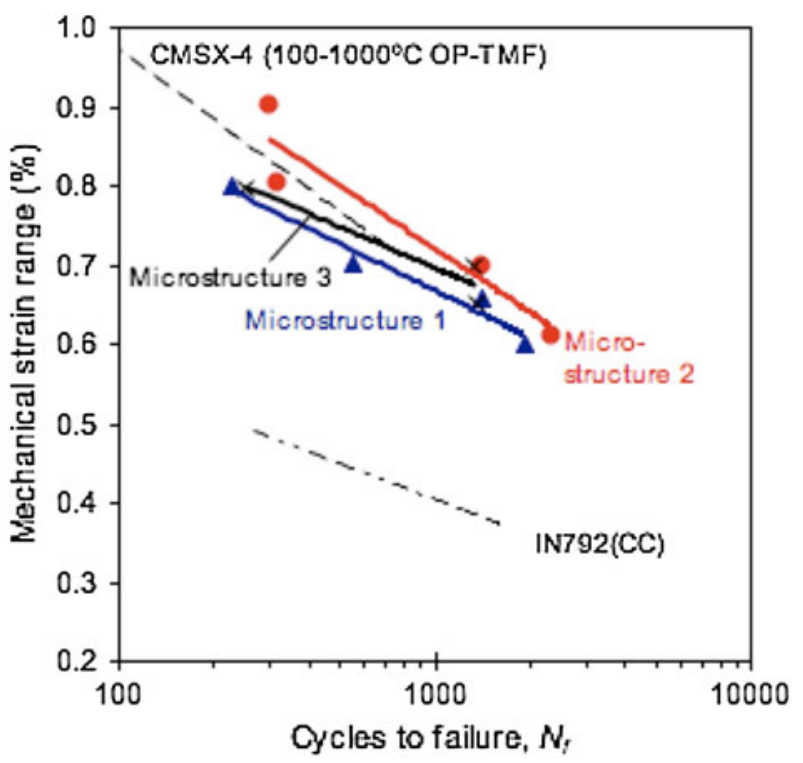

Fig. 14-TMF data for STAL-15, in which the number of cycles to failure is plotted against the mechanical strain range employed. Note the superior performance of the second microstructural condition.

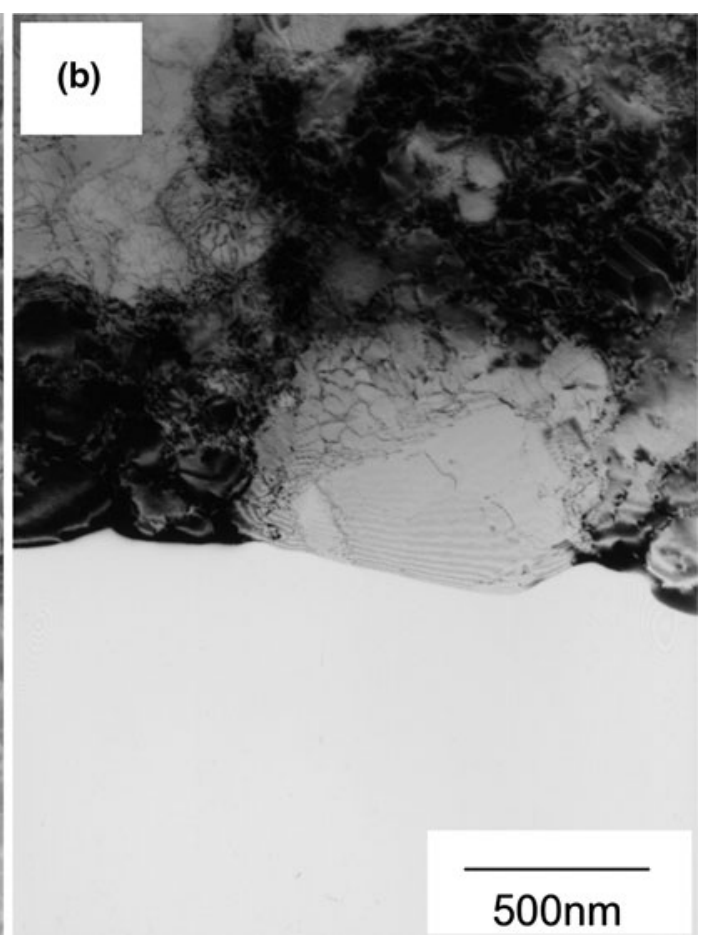

Fig. 13-TEM micrographs of STAL-15 (microstructure 3) after creep rupture testing at $(a) 1123 \mathrm{~K}\left(850{ }^{\circ} \mathrm{C}\right) / 275 \mathrm{MPa}$ and $(b) 1023 \mathrm{~K}\left(750{ }^{\circ} \mathrm{C}\right) /$ $520 \mathrm{MPa}$. 
activity being much less than in the case of the crept microstructures. These observations suggest that TMF damage is more highly localized than for creep and is limited to the proximity of the fracture surface. Also, the secondary $\gamma^{\prime}$ has dissolved during TMF testing (Figure 19).

\section{DISCUSSION: ON THE DAMAGE MECHANISMS OCCURRING IN TMF}

The TMF results presented here are interesting because the damage mechanisms found are very different from those reported in the literature so far. Significant research has been reported on the TMF of Re-containing single-crystal superalloys such as CMSX$4^{[21,24]}$ and TMS-82+; ${ }^{[9]}$ in these articles, the prevalent damage mechanism during TMF is mechanical twinning. Instead, in STAL-15, which does not have the benefit of the significant creep resistance of CMSX-4, the dominant mode of damage is localized slip band formation, with associated $\gamma^{\prime}$ shearing in these bands.

One should attempt to rationalize the factors influencing these differences in the deformation modes.

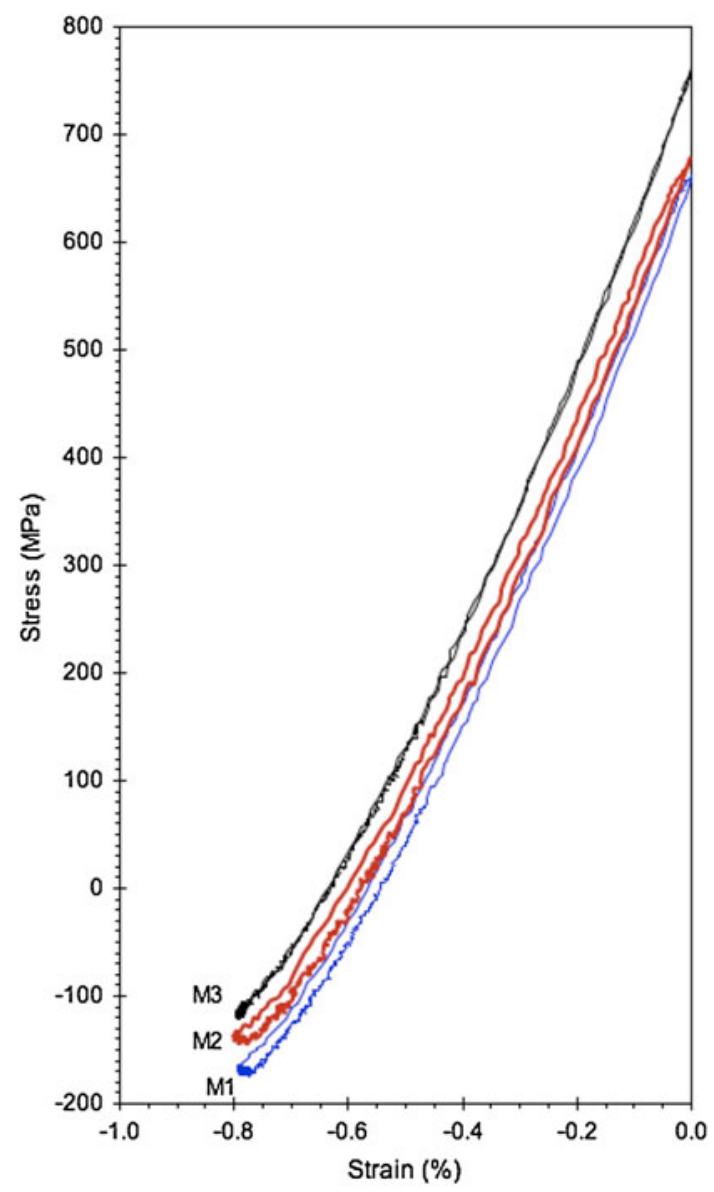

Fig. 15- Stabilized hysteresis loop at midlife for STAL-15 with three different microstructures (M1: microstructure 1, M2: microstructure 2, and M3: microstructure 3).
Generally, it is known that the transition from slip to twinning occurs when the localized stress exceeds a threshold stress; ${ }^{[25]}$ in this case, it can be expected that the gamma prime precipitates are penetrated. Moreover, careful work ${ }^{[9]}$ has revealed that it is the compressive stress when the number of accumulated TMF cycles is low that activates the twinning mode; our results support this view. In Figure 20, the hysteresis loops of
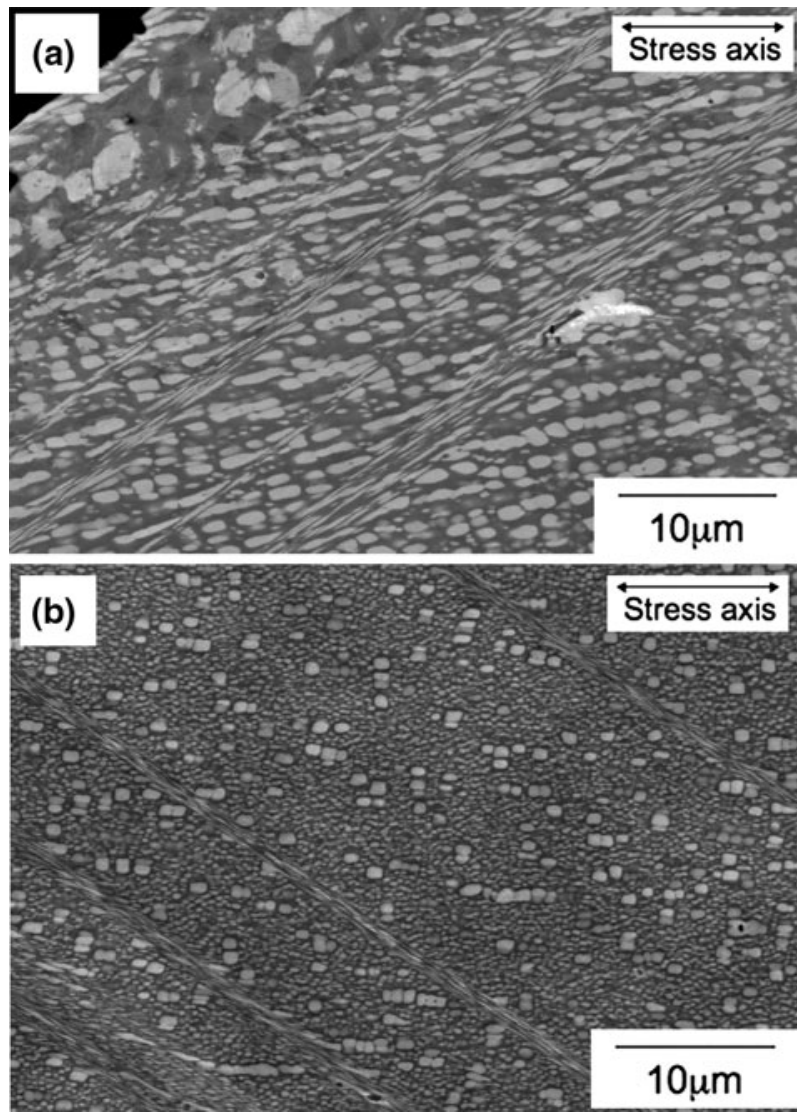

Fig. 16-Micrographs of STAL-15 after TMF testing: (a) microstructure 2 with $\Delta \varepsilon_{\text {mech }}=0.7$ pct and $(b)$ microstructure 3 with $\Delta \varepsilon_{\text {mech }}=$ 0.8 pct. The stress axis is in the horizontal direction in both cases.

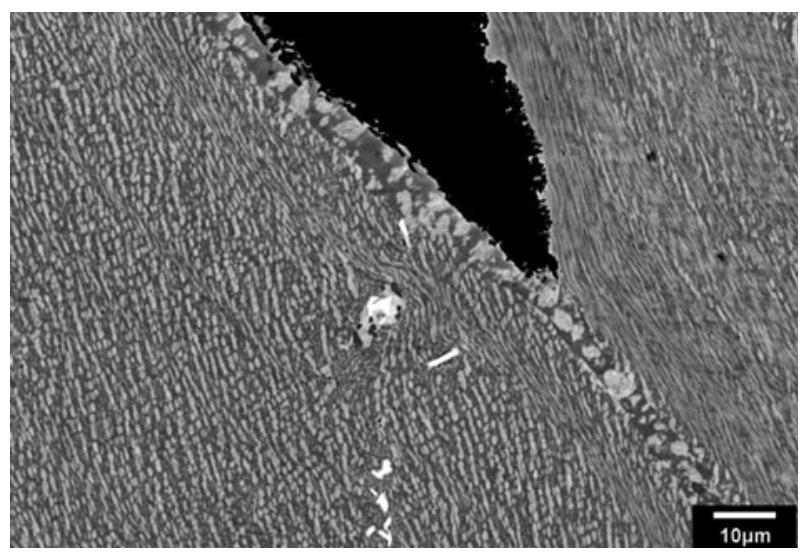

Fig. 17-TMF crack propagation along the recrystallized slip band observed in microstructure 2 with $\Delta \varepsilon_{\text {mech }}=0.7$ pct. 
the first TMF cycles observed in STAL-15 and CMSX$4^{[21,22]}$ are compared, for the mechanical strain range of 0.8 pct. For STAL-15, one can see that the highest stress is $\sim 550 \mathrm{MPa}$; this is compressive in nature and occurs at $\sim 1133 \mathrm{~K}\left(\sim 860^{\circ} \mathrm{C}\right)$ during the heating cycle, i.e., $\sim 40 \mathrm{~K}$ below the maximum temperature to which the material

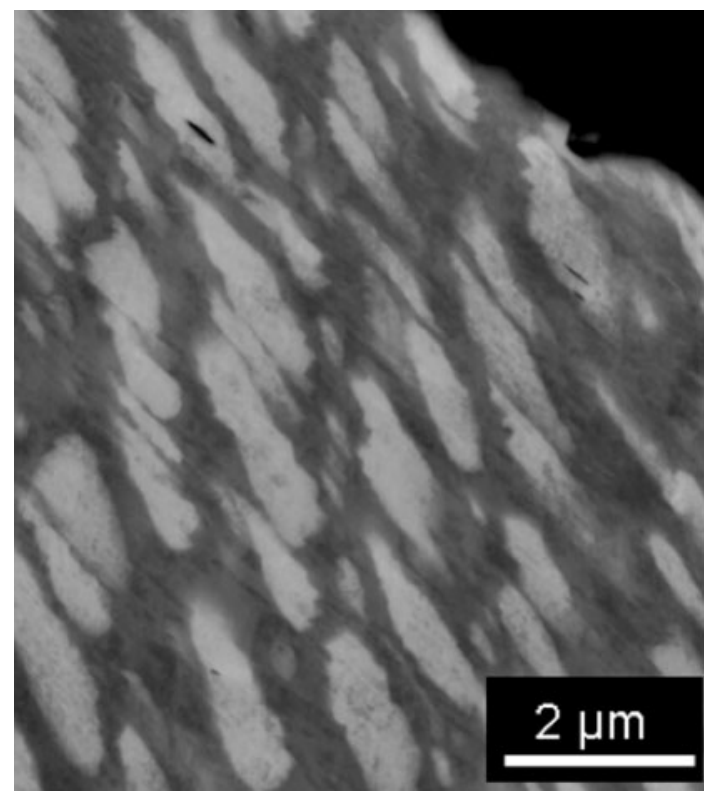

Fig. 18- Sheared $\gamma / \gamma^{\prime}$ observed in microstructure 2 after TMF testing with $\Delta \varepsilon_{\text {mech }}=0.7$ pct. Stress axis in vertical direction.

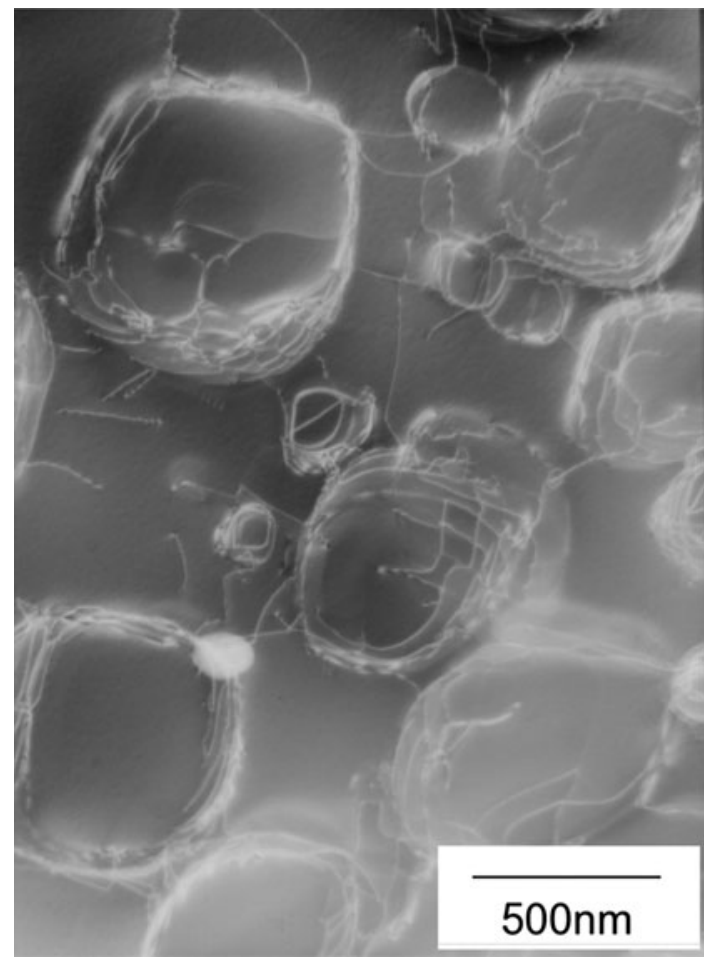

Fig. 19-TEM micrographs of STAL-15 after TMF testing in microstructure 2 with $\Delta \varepsilon_{\text {mech }}=0.7$ pet. is subjected. Note that CMSX-4 (which exhibits twinning rather than slip band formation) experiences a larger maximum compressive stress at a lower temperature, $\sim 1103 \mathrm{~K}\left(\sim 830{ }^{\circ} \mathrm{C}\right)$. Thus, it seems possible that the root cause of slip band formation in STAL-15 (and, therefore, a possible contribution to a TMF resistance, which almost matches that of CMSX-4) is its rather moderate high-temperature compressive creep strength.

The influence of different $\gamma^{\prime}$ morphologies on TMF performance should also be commented upon. The work here indicates that the resistance to shearing of the primary $\gamma^{\prime}$ particles is important in determining TMF resistance. Particle hardening theories ${ }^{[10,26]}$ indicate that the critical resolved shear stress for particle shearing is proportional to $\sqrt{ }(r f)$, where $r$ is the radius of primary $\gamma^{\prime}$ and $f$ is the volume fraction of $\gamma^{\prime}$, respectively. This enables a contour plot of critical resolved shear stress to be identified on which the fraction $f$ of the $\gamma^{\prime}$ phase is plotted against its particle radius $r$ (Figure 21). Provided that secondary $\gamma^{\prime}$ dissolved during TMF testing, the primary $\gamma^{\prime}$ size is solely plotted against the total volume fraction at highest temperature during TMF testing $\left(42\right.$ pct at $\left.1223 \mathrm{~K}\left(950{ }^{\circ} \mathrm{C}\right)\right)$. The highest strength is expected in the top right corner of the diagram when both $f$ and $r$ are large. Also plotted are the locations of microstructures 1 through 3 studied here and the values for $\sqrt{ }(r f)$ reported for CMSX-4. ${ }^{[11,27]}$ Note that $\sqrt{ }(r f)$ is higher toward the top right of this diagram. One can see that Figure 21 helps to rationalize the superior TMF performance of microstructure 2 and the relatively poorer performance of microstructure 1. Therefore, it seems likely that the $\gamma^{\prime}$ shearing resistance, i.e., $\sqrt{ }(r f)$, is a major factor influencing TMF resistance. Providing that

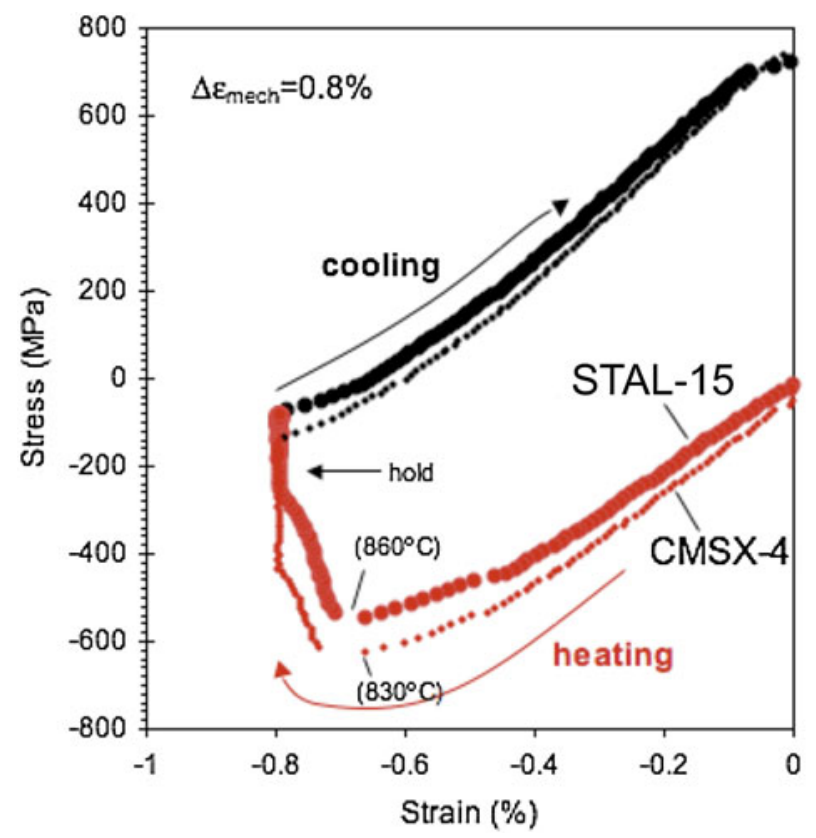

Fig. 20-Hysteresis loop from the first cycle of OP-TMF testing on STAL-15 with microstructure 1 and CMSX-4 with mechanical strain range of 0.8 pct. Maximum compressive stresses of $550 \mathrm{MPa}$ (STAL$15)$ and $625 \mathrm{MPa}(\mathrm{CMSX}-4)$ are identified at $\sim 1133 \mathrm{~K}$ and $\sim 1103 \mathrm{~K}$ $\left(\sim 860{ }^{\circ} \mathrm{C}\right.$ and $\left.\sim 830^{\circ} \mathrm{C}\right)$, respectively. 
the microtwinning mechanism prevalent in CMSX-4 can be avoided, this suggests that increasing the primary $\gamma^{\prime}$ size is beneficial.

Finally, the importance of $\gamma^{\prime}$ particle shearing in the mechanism of TMF explains why the optimum microstructure condition for creep was not the one that was optimum for TMF. At the creep conditions studied here, little or no $\gamma^{\prime}$ shearing occurs, as confirmed by the TEM studies; dislocation activity is restricted to the matrix phase. Under these circumstances, creep deformation is

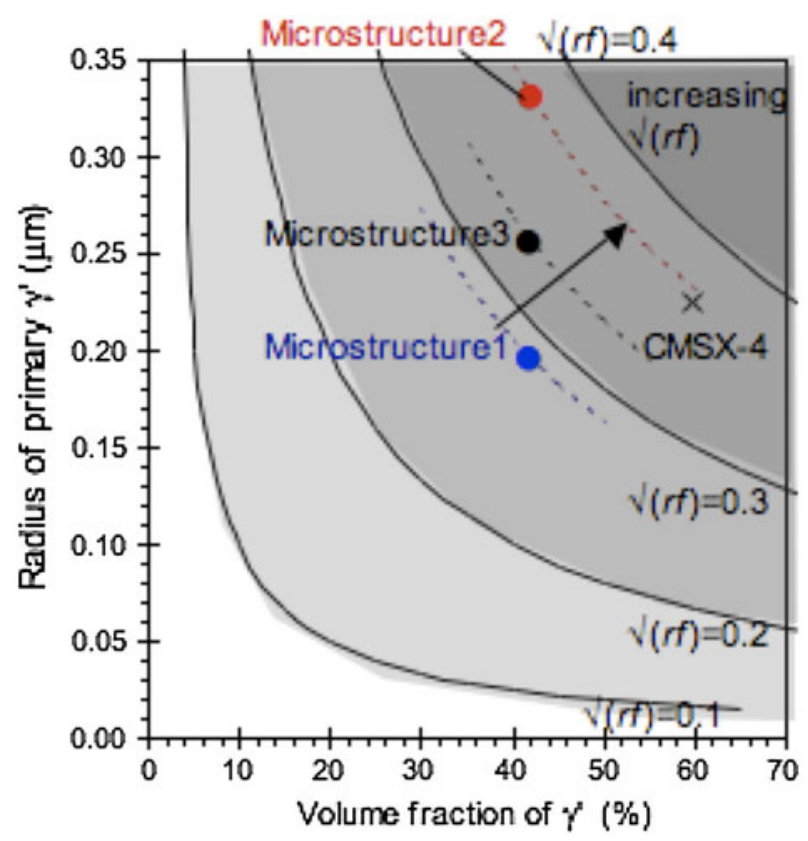

Fig. 21-Isocontour plot for the particle shearing mechanism in STAL-15. Reference data of CMSX-4 are also given. Note that the isocontours of $\sqrt{ }(r f)$ are given as solid lines. best limited by a uniform and regular precipitate structure. ${ }^{[10,28]}$ In fact, creep relaxation occurs during TMF testing, as can be seen at the hot end of the first TMF cycle for microstructures 1 through 3 (Figure 22). One can see that microstructure 1 exhibits superior creep relaxation behavior at both mechanical strain range conditions considered. The creep relaxation differences are small $(<50 \mathrm{MPa})$, but the TMF data are consistent with the static creep results, which indicate that microstructure 1 shows the slowest creep deformation to $1 \mathrm{pct}$ creep strain.

\section{ON THE FACTORS CONTROLLING TMF RESISTANCE IN SINGLE-CRYSTAL SUPERALLOYS}

This work provides important insights into the factors controlling the TMF performance of single-crystal superalloys, which are not well understood at present. These can be summarized as follows. A first point is that the best performance in TMF and that in creep do not necessarily go hand in hand; thus, for resistance to TMF, an alloy does not need the very best creep resistance. Thus, it has been demonstrated that a Re-free alloy (STAL-15) can perform just as well in TMF as a Re-containing one (CMSX-4) despite the creep resistance being markedly inferior.

A second point relates to the difference in the damage modes that are prevalent. In STAL-15, one sees slip bands and then recrystallization within these bands followed by fatigue cracking along them. Some shearing occurs of the rafts of $\gamma^{\prime}$, which for OP TMF and a negatively misfitting alloy are elongated along the direction of applied load. In CMSX-4, on the other hand, deformation is more localized and the microtwinning mode is more prevalent. ${ }^{[21,22]}$ Recrystallization and precipitation of topologically-close-packed phases

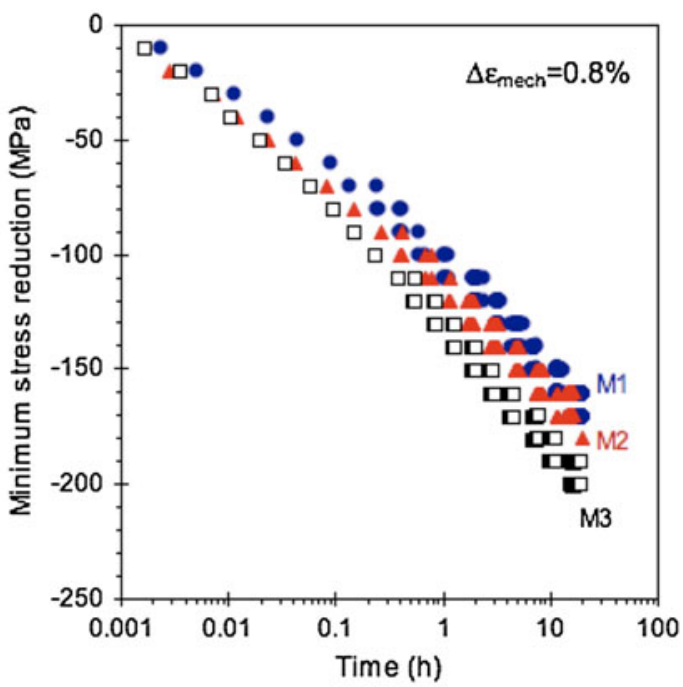

(b)

Fig. 22-Creep relaxation data observed in microstructures 1 through 3 during the holding period in the first cycle of TMF testing: (a) $\Delta \varepsilon_{\text {mech }}=0.7$ pct and (b) $\Delta \varepsilon_{\text {mech }}=0.8$ pct. 
(TCPs) along the twins can occur, and this is again the preferred direction of crack propagation. Once again, these differences underline the important influence of alloy chemistry on TMF resistance.

A third point relates to the optimum microstructure for TMF. At least for the STAL-15-type compositions, which are free of $\mathrm{Re}$, optimum TMF resistance is conferred when the resistance to $\gamma^{\prime}$ shearing is greatest. Consistent with a critical resolved shear stress proportional to $\sqrt{ }(r f)$, where $r$ is the radius of primary $\gamma^{\prime}$ and $f$ is the volume fraction of $\gamma^{\prime}$, respectively, TMF performance is improved at large $r$ and presumably if $f$ is increased, although this last point is not tested here. Whether this is also true for the Re-containing alloys, which are prone to microtwinning, needs to be tested via further experimentation, and is the subject of ongoing research.

In the case of STAL-15, its suitability for gas turbine applications rests on, in conjunction with its superior environmental performance, ${ }^{[5,6]}$ its rather good TMF performance, which, in turn, is conferred by its resistance to precipitate shearing. It has a wide solutioning window and can be heat treated readily to yield a microstructure that confers the necessary mechanical performance.

\section{CONCLUSIONS}

The following conclusions can be drawn from this work.

1. A prototype high $\mathrm{Cr}$-containing nickel-base singlecrystal superalloy STAL-15 has been assessed to determine the factors influencing the mechanical performance in creep and OP TMF.

2. Neutron diffraction studies confirmed that STAL-15 has a gamma prime fraction of approximately 42 pet at $1223 \mathrm{~K}\left(950{ }^{\circ} \mathrm{C}\right)$, increasing to approximately 56 pct at $1073 \mathrm{~K}\left(800{ }^{\circ} \mathrm{C}\right)$. The lattice misfit is small, ranging from -0.09 pet at $1073 \mathrm{~K}\left(800^{\circ} \mathrm{C}\right)$ to -0.20 pet at $1273 \mathrm{~K}\left(1000^{\circ} \mathrm{C}\right)$.

3. The TMF response of the new alloy STAL-15 is comparable to that of the commonly employed singlecrystal superalloy CMSX-4; this is despite the fact that the constant load (static) creep performance is inferior to it and in fact more broadly consistent with the polycrystalline superalloy IN792.

4. The factors controlling TMF resistance are distinct from those determining creep; in particular, for best TMF performance, resistance to dislocation shearing of the gamma prime phase is required-consistent with a large flow stress and ultimate tensile strength. On the other hand, at least for low stresses, creep resistance is determined by dislocation activity in the gamma matrix phase.

5. The influence of primary gamma prime size was investigated. The TMF resistance increases with increasing primary gamma prime size; in creep, the finer primary gamma prime microstructure gave better performance, particularly in the high-temperature regime due to rafting.
6. Consistent with the lower elastic moduli, the TMF performance of STAL-15 is superior to that of the polycrystalline alloy IN792 when the mechanical strain range is considered. The data for the mechanical strain range are sensitive to the microstructural state, with the data indicating that a bimodal microstructure with large gamma prime particles performs best.

\section{ACKNOWLEDGMENTS}

The authors are grateful to Siemens Industrial Turbomachinery AB in Sweden for sponsoring this work. The invaluable advice and support of Dr. Cathie Rae, University of Cambridge, is acknowledged. Mr. Peter Cranmer, University of Birmingham, for casting, Ms. Ming Chu for TEM foil preparation, Mr. Frank Biddlestone for DSC, Dr. Edward Oliver, ISIS, and Dr. David Dye, Imperial College London, for in-situ neutron diffractometry are thanked for their invaluable assistance.

\section{REFERENCES}

1. T.M. Pollock and A.S. Argon: Acta Metall. Mater., 1994, vol. 42, pp. 1859-74.

2. F.R.N. Nabarro and H.L. deVilliers: The Physics of Creep, Taylor \& Francis, London, 1995.

3. A.G. Evans, M.Y. He, A. Suzuki, M. Gigliotti, B. Hazel, and T.M. Pollock: Acta Mater., 2009, vol. 57, pp. 2969-83.

4. F. Pyczak, B. Devrient, F.C. Neuner, and H. Mughrabi: Acta Mater., 2005, vol. 53, pp. 3879-91.

5. A. Sato, Y.L. Chiu, and R.C. Reed: Acta Mater., 2011, vol. 59, pp. 225-40.

6. M. Hasselqvist, R.C. Reed, J.J. Moverare, and A. Sato: 1st Int. Symp. on Eurosuperalloys, 2010, unpublished research.

7. Proc. Superalloys 2008, 11th Int. Symp. for Superalloys, R.C. Reed, K.A. Green, P. Caron, T.P. Gabb, and M.G. Fahrmann, and E.S. Huron, eds., TMS, Warrendale, PA, 2008.

8. H. Mughrabi, S. Kraft, and M. Ott: Superalloys 1996, R.D. Kissinger, D.J. Deye, D.L. Anton, A.D. Cetel, M.V. Nathal, T.M. Pollock, and D.A. Woodford, eds., TMS, Warrendale, PA, 1996, pp. 335-44.

9. J.X. Zhang, H. Harada, Y. Ro, Y. Koizumi, and T. Kobayashi: Acta Mater., 2008, vol. 56, pp. 2975-87.

10. R.C. Reed: The Superalloys-Fundamentals and Applications, Cambridge University Press, Cambridge, United Kingdom, 2006.

11. Thermotech Ni-Data Version 6, Thermotech Ltd./Sente Software, Surrey, United Kingdom.

12. R.A. Stevens and P.E.J. Flewitt: Acta Metall., 1981, vol. 29, pp. $867-82$.

13. I.M. Lifshitz and V.V. Slyozov: J. Phys. Chem. Solids, 1961, vol. 19, pp. 35-50.

14. C. Wagner: Z. Elektrochem, 1961, vol. 65, pp. 581-91

15. A.J. Ardell and R.B. Nicholson: Acta Metall., 1966, vol. 14, pp. 1295-1309.

16. A.J. Ardell: Acta Metall., 1968, vol. 16, pp. 511-16.

17. H.A. Calderon, P.W. Voorhees, J.L. Murray, and G. Kostorz: Acta Metall. Mater., 1994, vol. 42, pp. 991-1000.

18. X. Li, N. Saunders, and A.P. Miodownik: Metall. Mater. Trans. A, 2002, vol. 33A, pp. 3367-73.

19. W.J. Boettinger, U.R. Kattner, S.R. Coriell, Y.A. Chang, and B.A. Mueller: in Modeling of Casting, Welding and Advanced Solidification Processes VII, M. Cross and J. Campbell, eds., TMS, Warrendale, PA, 1995, pp. 649-56.

20. M.S.A. Karunaratne and R.C. Reed: Acta Mater., 2003, vol. 51, pp. 2905-19.

21. J.J. Moverare, S. Johansson, and R.C. Reed: Acta Mater., 2009, vol. 57, pp. 2266-76. 
22. J.J. Moverare and S. Johansson: Mater. Sci. Eng., 2010, vol. 527A, pp. $553-58$.

23. J.J. Moverare: University of Linkorping, Sweden, 2012, unpublished research.

24. J.X. Zhang, Y. Ro, H. Zhou, and H. Harada: Scripta Mater., 2006, vol. 54, pp. 655-60.
25. M.A. Meyers, O. Vohringer, and V.A. Lubarda: Acta Mater., 2001, vol. 49, pp. 4025-39.

26. A.J. Ardell: Metall. Trans. A, 1985, vol. 16A, pp. 2131-65.

27. K. Harris and G.L. Erickson: Patent No. US4643782, Feb. 17, 1987.

28. P. Caron, P.J. Henderson, T. Khan, and M. McLean: Scripta Metall., 1986, vol. 20, pp. 875-80. 